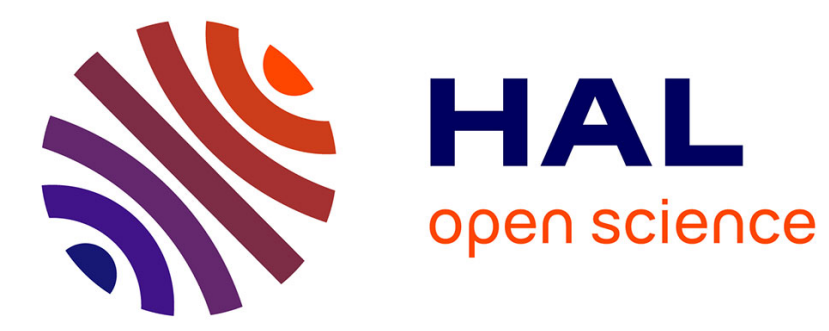

\title{
Variation in the decay resistance of larch to fungi
}

Yannick Curnel, Dominique Jacques, Notburga Gierlinger, Luc Pâques L.E.

\section{To cite this version:}

Yannick Curnel, Dominique Jacques, Notburga Gierlinger, Luc Pâques L.E.. Variation in the decay resistance of larch to fungi. Annals of Forest Science, 2008, 65 (8), pp.1-8. 10.1051/forest:2008062 . hal-02661871

\section{HAL Id: hal-02661871 \\ https://hal.inrae.fr/hal-02661871}

Submitted on 30 May 2020

HAL is a multi-disciplinary open access archive for the deposit and dissemination of scientific research documents, whether they are published or not. The documents may come from teaching and research institutions in France or abroad, or from public or private research centers.
L'archive ouverte pluridisciplinaire HAL, est destinée au dépôt et à la diffusion de documents scientifiques de niveau recherche, publiés ou non, émanant des établissements d'enseignement et de recherche français ou étrangers, des laboratoires publics ou privés. 


\title{
Variation in the decay resistance of larch to fungi
}

\author{
Yannick CURnEL $^{1 *}$, Dominique JACQUES ${ }^{1}$, Notburga GIERLINGER ${ }^{2}$, Luc E. PÂQUES ${ }^{3}$ \\ ${ }^{1}$ Centre de Recherche de la Nature, des Forêts et du Bois, DGRNE, Ministère de la Région wallonne, avenue Maréchal Juin, 23, \\ B-5030 Gembloux, Belgium \\ ${ }^{2}$ Max-Planck-Institute of Colloids and Interfaces, Department of Biomaterials, D-14424 Potsdam, Germany \\ ${ }^{3}$ INRA, Unité d'Amélioration, de Génétique et de Physiologie des Arbres Forestiers, F-45166 Olivet Cedex, France
}

(Received 10 March 2008; accepted 30 August 2008)

Keywords: natural durability /

fungus /

Larix /

genetics /

environmental effect

\begin{abstract}
- Decay resistance of larch (Larix sp.) to fungi was evaluated on heartwood samples belonging to 3 species (L. decidua, L. kaempferi and their hybrid), 3 races of European larch (polonica, sudetica and alpine), 13 wood lots (populations) and 313 trees.

- Larch wood appeared, on average, as moderately durable although a high variability was observed. At the sample level as well as at the mean individual tree level, durability ranged from class 1 to 5 according to EN 350-1 standard. At the population level, larch wood varied from 'durable' to 'slightly durable'. Genetics played a major role in decay resistance at the species, provenance and tree levels. Environmental factors such as the position of heartwood samples and the age of trees were also identified as a source of variability.

- The most durable wood was not necessarily from old native alpine stands of European larch: some young larches from faster growing lowland origins also produced durable wood.

- Genetic improvement of larch wood durability appeared therefore likely by the selection of the best populations for decay resistance as well as from the selection of individuals.
\end{abstract}

Résumé - Variabilité de la résistance à la dégradation du bois de mélèze par les champignons. - La résistance à la dégradation du bois de duramen du mélèze (Larix sp.) est évaluée à partir d'un échantillon d'éprouvettes extraites de 313 arbres appartenant à 3 espèces (L. decidua, L. kaempferi et leur hybride), 3 races de mélèze européen (polonica, sudetica et alpine) et 13 lots différents.

- Le bois de mélèze apparaît, en moyenne, comme 'modérément durable', mais une grande variabilité due à plusieurs facteurs a été observée. Au niveau arbres et échantillons, la durabilité naturelle s'étend de la classe 1 à 5 suivant la norme EN 350-1. Suivant les origines, le bois de mélèze peut être classé comme 'durable' à 'faiblement durable'. Les facteurs génétiques jouent un rôle significatif sur la résistance à la dégradation du bois aux niveaux espèce, provenance et arbre. Des facteurs environnementaux tels que la position des échantillons au sein du duramen et l'âge des arbres ont également été mis en évidence.

- Le bois à plus forte durabilité ne provient pas exclusivement des vieux peuplements naturels de mélèze alpin : certaines origines de mélèze cultivées à basse altitude et constituées d'arbres plus jeunes et à croissance rapide peuvent aussi produire du bois durable.

- L'amélioration génétique de la durabilité naturelle du mélèze apparait donc comme envisageable au travers de la sélection des meilleures populations et des meilleurs individus.

\section{INTRODUCTION}

Larch, especially European larch, has traditionally held a good reputation in the Alps as a source of building material. This reputation is based upon its excellent mechanical properties combined with its good natural durability out of soil contact (Collardet and Besset, 1988). In addition to the wood

*Corresponding author: curnel@cra.wallonie.be quality itself, it seems obvious that the longevity of these constructions also relies on a high ancestral level of building expertise.

In contrast, the apparent natural durability and longevity qualities of larch wood do not seem to be expressed in the same way outside its distribution within the Alps. Nilsson (1997) concluded that larch wood durability has a large base of variability and, as observed in other studies (Gambetta et al., 2004; Rapp et al., 2002; Venäläinen et al., 2001; Viitanen 
Table I. General description of the collection sites.

\begin{tabular}{|c|c|c|c|c|c|c|c|c|c|}
\hline Name & Country & Latitude & Longitude & $\begin{array}{c}\text { Altitude } \\
\text { (m) }\end{array}$ & $\begin{array}{c}\text { Climate } \\
\text { type }\end{array}$ & $\begin{array}{c}\text { Annual } \\
\text { rainfall } \\
(\mathrm{mm})\end{array}$ & $\begin{array}{c}\text { Mean annual } \\
\text { temperature } \\
\left({ }^{\circ} \mathrm{C}\right)\end{array}$ & Nature of stand & $\begin{array}{c}\text { Stand age } \\
(\mathrm{y})\end{array}$ \\
\hline Coat-An-Noz & France & $3^{\circ} 25^{\prime} \mathrm{W}$ & $48^{\circ} 31^{\prime} \mathrm{N}$ & 200 & Oceanic & 890 & 10.5 & Provenance trial & $41-42$ \\
\hline Elm (Brunsleberfeld) & Germany & $10^{\circ} 03^{\prime} \mathrm{E}$ & $52^{\circ} 00^{\prime} \mathrm{N}$ & 205 & Oceanic & 700 & 7.8 & Provenance trial & $41-43$ \\
\hline Langau & Austria & $15^{\circ} 10^{\prime} \mathrm{E}$ & $47^{\circ} 49^{\prime} \mathrm{N}$ & 1050 & Mountain & 1742 & 8.0 & Native stand & around 185 \\
\hline Montgenèvre & France & $6^{\circ} 44^{\prime} \mathrm{E}$ & $44^{\circ} 56^{\prime} \mathrm{N}$ & 2200 & Mountain & 714 & 7.6 & Native stand & $>220$ \\
\hline
\end{tabular}

Table II. List and details of the collected materials.

\begin{tabular}{|c|c|c|c|c|c|c|c|}
\hline Wood lot & $\begin{array}{l}\text { Race/ } \\
\text { Origin }\end{array}$ & Provenance & Stand & $\begin{array}{l}\text { Country } \\
\text { of trees }\end{array}$ & $\begin{array}{c}\text { Number } \\
(\mathrm{m})\end{array}$ & $\begin{array}{l}\text { Mean height } \\
(\mathrm{cm})\end{array}$ & Average diameter \\
\hline Langau-B & Alps & Langau (A) & Nassogne & Belgium & 20 & 24.4 & 30.3 \\
\hline Ruda-F & Sudetan Mts & Ruda (CZ) & Coat-An-Noz & France & 20 & 21.4 & 29.0 \\
\hline Zabreh-B & Sudetan Mts & Zabreh (CZ) & Nassogne & Belgium & 19 & 27.5 & 34.9 \\
\hline Zabreh-F & Sudetan Mts & Zabreh (CZ) & Coat-An-Noz & France & 20 & 20.3 & 27.1 \\
\hline \multicolumn{8}{|l|}{ Group 2} \\
\hline Hybrid-GB & Hybrid GB & 4 full-sib-families & Clanna (England) & Great-Britain & 36 & 28.1 & 55.7 \\
\hline Hybrid-F & Hybrid F & Full-sib family & Coat-An-Noz & France & 30 & 23.5 & 32.4 \\
\hline Montgenèvre-nat & Alps & Montgenèvre (native range) & Montgenèvre & France & 30 & 26.9 & 51.4 \\
\hline Langau-nat & Alps & Langau (native range) & Langau & Austria & 30 & 33.2 & 50.5 \\
\hline Ruda-D & Sudetan Mts & Ruda $(\mathrm{CZ})$ & Elm (Brunsleberfeld) & Germany & 30 & 26.0 & 30.4 \\
\hline
\end{tabular}

et al., 1997), larch wood can be considered as 'not durable' up to 'durable' according to the European standards (NBNEN 350-1, 1994; NBN-EN 350-2, 1994). Works reported in this review are mainly issued from Northern European countries and concern other larch species or European larch races different from alpine larch.

In Europe most genetic improvement programs for larch are geared towards increasing plantation areas outside the natural Alpine distribution area to the warmer, more fertile regions of the lowlands. They have therefore favoured the well adapted lowland Central European provenances (Jacques, 1991; Pâques, 1996a; Schöber 1977), Japanese larch (Pâques, 1996b) and their interspecific hybrids (Pâques, 1989; 2002; Philippe et al., 2002; Schneck et al., 2002) which combine a good resistance to larch canker with a fast growing potential. Given the increasing demand for larch wood and that current forestry tends to favour fast growing species, it is crucial to critically evaluate the quality of the raw material derived from these lowland based improvement programs. It is also essential to clearly identify the main sources of variability to natural durability within and between species in order to better understand differing results from the literature.

Heartwood is the most valuable part of larch timber. In contrast to most conifers, its production is precocious and always abundant. However, high variability of heartwood/sapwood extent at different genetic levels (populations, progenies and clones) has been shown together with a high genetic control (Pâques, 2001). Unfortunately such information regarding nat- ural durability properties is unavailable. Selection for both quantitative (production) and qualitative (durability) characteristics of larch heartwood is a main issue as selection for durable wood could help reduce the use of artificially preserved products whose toxicity is criticized (Fields, 2001; Sailer and van Etten, 2004).

Results presented in this study are part of a larger project evaluating properties of larch wood from lowland plantations through anatomical, chemical, biological, physical and mechanical characterisation. Some results have already been reported (Gierlinger, 2003; Gierlinger et al., 2003; 2004a; 2004b; Jacques et al., 2002). This study evaluates the variability of natural durability among larch species and among and within provenances of European larch. The impact and consequences of these differences for tree breeders and foresters are also estimated.

\section{MATERIAL AND METHODS}

\subsection{Material origin}

Three hundred and thirteen trees growing on 6 different sites were harvested. Three sites were International Union Forestry Research Organisation (IUFRO) provenance trials, two were alpine natural stands and one a hybrid larch progeny test (Tab. I). A total of 13 wood lots were analysed including 3 species, namely European larch (10 lots), Japanese larch (1 lot) and hybrid larch (2 lots) (Tab. II). 
For European larch, 5 different provenances (Montgenèvre, Langau, Ruda, Zabreh, Blizyn) belonging to three different races (polonica, sudetica and alpine) were sampled. For two of these European provenances (Langau and Montgenèvre), two different stands were sampled: one from the native region in the Alps and the second from its progeny grown in the IUFRO trials. The number of trees per lot varied between 18 and 36 . With the exception of trees from alpine natural stands, all the harvested trees were of similar age (between 41 and 44 years from seed). Due to the high number of trees, the harvest took place during two different periods: the first group of trees (group 1, Tab. II) was collected during winter 1998-1999 and the second during 2000. The second set (group 2, Tab. II) was felled during two different seasons; half of the trees from each provenance were cut down at the beginning of 2000 after flushing and then left in the forest with their branches until autumn, while the remainder were harvested during autumn 2000. A $2 \mathrm{~m}$ long basal $\log$ was sampled $50 \mathrm{~cm}$ above the stump from all trees.

\subsection{Sample preparation and natural durability analysis}

A central board including the pith was sawn from each harvested $\log$. Twenty-four samples, 6 of the inner part and 6 of the outer part of the heartwood, from both sides of the pith of each log, were then prepared according to the European standard EN 350-1 (NBN-EN $350-1,1994)$. From the 24 samples, 16 were tested for natural durability and the 8 remaining samples used as standards to calculate the reference dry matter for the different samples.

Natural durability was evaluated for 4702 samples. Half of the samples were inoculated with Poria placenta (strain FPRL280) and half with Coniophora puteana (strain FPRL11E). Samples were then incubated in Kolle flasks in a conditioning room for 16 weeks. Following exposure, mycelium was removed from the samples before they were oven dried to constant weight. The difference between the reference dry matter weight and the dry matter weight measured after fungal decay provided the loss of dry matter.

Two hundred and seventy-four Scots pine (Pinus sylvestris L.) sapwood samples were prepared and used as a control to determine the natural durability level of each larch sample. The natural durability level was computed according to the European standard EN 350-1 (NBN-EN 350-1, 1994) as the ratio between the weight loss of a larch sample and the average weight loss of the Scots pine samples.

Any samples with a moisture content greater than $100 \%$ at the end of the process were rejected (water logging); 4671 larch samples and 243 Scots pine samples were ultimately considered.

\subsection{Statistical analysis}

Natural durability of the different wood samples was evaluated on the basis of the average mass loss. As recommended in the European standard EN 350-1 (NBN-EN 350-1, 1994), analyses were performed on the most aggressive of the two fungi.

Variation in natural durability among larch species and among and within provenances of European larch was analysed using the position on tree and site as explanatory variables.

The position of the wood sample in the log (inner and outer part of heartwood) was subjected to a one-way analysis of variance. The site where trees were collected was the second tested effect. A lack of site effect was required in order to strictly compare provenances from
Table III. Number of observations, mean, standard deviation, coefficients of variation (\%), minimum and maximum for the percentage of mass loss per fungus and per position in the tree.

\begin{tabular}{lccccccc}
\hline \multicolumn{8}{c}{ Wood weight loss $(\%)$} \\
\hline Fungus & Position in tree & $n$ & Mean & St. Dev. & C.V. & Min. & Max. \\
\hline P. placenta & Inner & 1109 & 17.7 & 6.2 & 35 & 3.0 & 38.2 \\
& Outer & 1241 & 15.0 & 5.9 & 40 & 0.8 & 32.6 \\
& Overall & 2350 & 16.3 & 6.2 & 38 & 0.8 & 38.2 \\
\hline C. puteana & Inner & 1080 & 23.6 & 15.1 & 64 & 0.2 & 66.2 \\
& Outer & 1241 & 17.6 & 12.6 & 71 & 0.3 & 61.8 \\
& Overall & 2321 & 20.4 & 14.1 & 69 & 0.2 & 66.2 \\
\hline
\end{tabular}

different sites. To test the potential effect of sites, a two-way analysis of variance was performed for 2 common provenances (Ruda and Zabreh) on 2 contrasted sites (Nassogne and Coat-An-Noz) according to the following linear model:

$$
Y_{i j k}=\mu+P_{i}+s_{j}+(P s)_{i j}+D_{i j k}
$$

with $Y_{i j k}=$ the natural durability level of the sample $k$ of provenance $\mathrm{i}$ in site $j, \mu=$ the general mean, $P_{i}=$ deviation to the general mean due to provenance i (random factor), $s_{j}=$ deviation to the general mean due to site $j$ (fixed factor), $(P s)_{i j}=$ deviation to the general mean attributable to the interaction between the provenance $i$ and the site $j$, $D_{i j k}=$ residual deviation.

The variability of wood decay resistance among wood lots was then assessed only on lowland provenances as provenances from natural stands were much older and age has been reported to influence natural durability (Van Acker et al., 2003; Viitanen et al., 1997).

Species effect was studied with a one-way analysis of variance and the different species were compared using a Tukey's test.

The inter-race and the inter/intra-provenance variabilities were subsequently evaluated according to the following analysis of variance (fully hierarchised model):

$$
Y_{i j k l}=\mu+r c_{i}+P(r c)_{i j}+T(P r c)_{i j k}+D_{i j k l}
$$

with $Y_{i j k l}=$ the natural durability level of the wood sample 1 coming from tree $k$ of provenance $j$ belonging to race $i, \mu=$ the general mean, $r c_{i}=$ deviation to the general mean attributable to race $i$ (fixed factor), $P(r c)_{i j}=$ deviation to the general mean attributable to provenance $j$ belonging to race $i$ (random factor), $T(\operatorname{Prc})_{i j k}=$ deviation to the general mean attributable to the tree $k$ of provenance $j$ belonging to race $i$ (random factor) and $D_{i j k l}=$ residual deviation.

Statistical analyses were carried out with the statistical softwares SAS and R (R development Core Team, 2005; SAS Institute Inc., 2003) and with GLM procedures (type III S.S. due to the unbalanced nature of the data set). The effect of felling dates, previously tested by Jacques et al. (2002), was regarded as insignificant.

\section{RESULTS}

\subsection{Mean results}

C. puteana proved to be the most aggressive of the two fungi tested (Tab. III). On average, larch wood samples lost approximately $20 \%$ of their mass after incubation with 


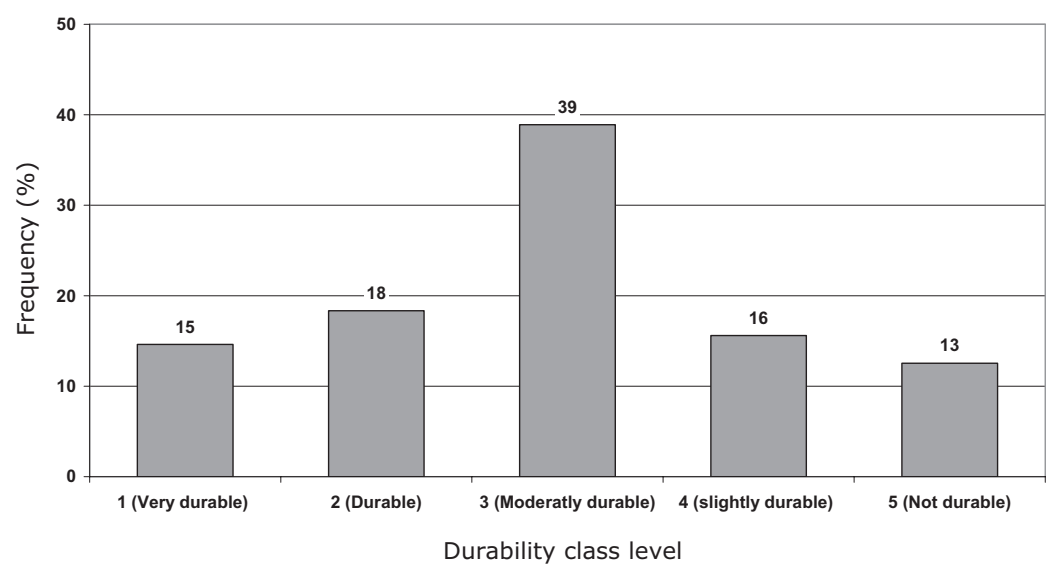

Figure 1. Distribution of wood samples according to the durability class levels defined in the European standard EN 350-1 for C. Puteana.

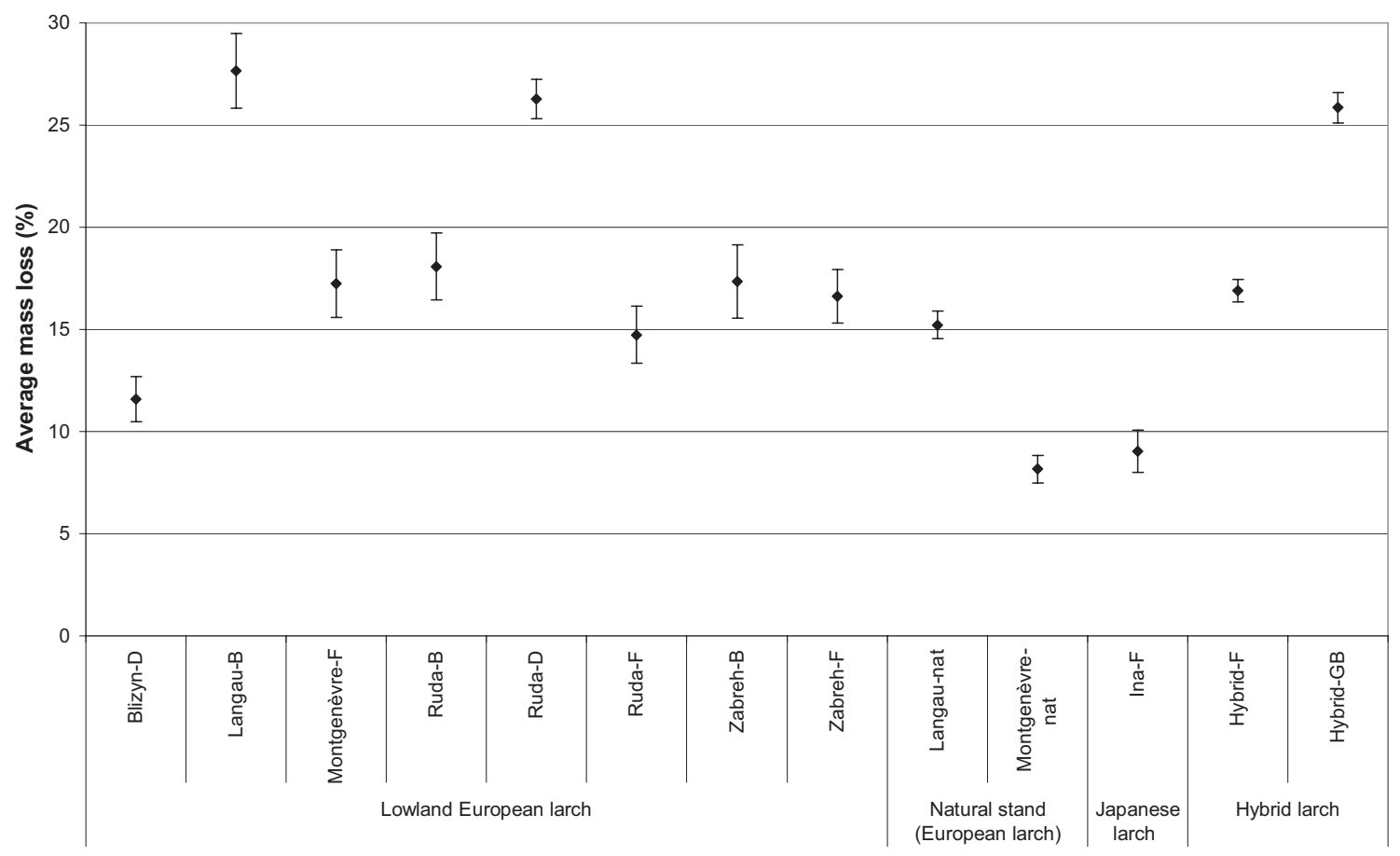

Figure 2. Average mass loss $(\% \pm \mathrm{SE})$ per provenance of outer wood samples for C. puteana.

C. puteana and $16 \%$ with P. placenta. The variability for mass loss among wood samples was twice as high with $C$. puteana than with $P$. placenta.

According to the European standard EN 350-1 (NBNEN 350-1, 1994) durability classes, the larch wood samples showed a large variability in decay resistance against C. puteana (Fig. 1). Durability ranged from class 1 (very durable) to class 5 (not durable), however more than $72 \%$ of the samples were classified as 'moderately durable' to 'very durable'. Only $13 \%$ fell into class 5 and were considered 'not durable'.

Analysis of variance showed that mass loss in the radial position was significantly higher in the inner part of the heartwood (juvenile wood) than in the outer part, sawn in the mature wood (Tab. III; F $=109.9, p<0.0001, d f=1,2319$ for $C$. puteana and $\mathrm{F}=124.8, p<0.0001, d f=1,2348$ for P. placenta).

Further analyses only considered the most aggressive fungus $C$. puteana and were based only on the outer wood samples. According to the European standard EN 350-1, only the most aggressive fungus has to be considered for the determination of durability class and mature wood is commonly considered as the most valuable part of larch trees for commercial uses.

\subsection{Variability among and within wood lots}

Large variability in decay resistance was observed among wood lots (Fig. 2). While wood from the provenances 
Table IV. Frequency distribution of trees and samples according to durability class.

\begin{tabular}{|c|c|c|c|c|c|c|c|c|}
\hline Wood lot & Taxa & Class 1 & Class 2 & Class 3 & Class 4 & Class 5 & Class $1+2$ & Class $1+2+3$ \\
\hline Blizyn-D & European larch & $5 / 25$ & $30 / 25$ & $60 / 30$ & $5 / 14$ & $-/ 6$ & $35 / 50$ & $95 / 80$ \\
\hline Langau-B & European larch & $-/ 5$ & $-/ 9$ & $15 / 20$ & $50 / 18$ & $35 / 48$ & $-/ 14$ & $15 / 34$ \\
\hline Montgenèvre- $\mathrm{F}$ & European larch & $6 / 18$ & $6 / 18$ & $49 / 28$ & $33 / 18$ & $6 / 18$ & $12 / 36$ & $61 / 64$ \\
\hline Ruda-B & European larch & $-/ 18$ & 15 / 18 & $55 / 25$ & $15 / 16$ & $15 / 23$ & $15 / 36$ & $70 / 61$ \\
\hline Ruda-D & European larch & $-/ 1$ & $3 / 12$ & $73 / 59$ & $24 / 23$ & $-/ 5$ & $3 / 13$ & $76 / 72$ \\
\hline Ruda-F & European larch & $5 / 20$ & $20 / 21$ & $45 / 27$ & $20 / 18$ & $10 / 14$ & $25 / 41$ & $70 / 68$ \\
\hline Zabreh-B & European larch & $5 / 26$ & 15 / 15 & $30 / 23$ & $35 / 15$ & $15 / 21$ & $20 / 41$ & $50 / 64$ \\
\hline Zabreh-F & European larch & $-/ 11$ & $11 / 22$ & $37 / 26$ & $52 / 22$ & $-/ 19$ & $11 / 33$ & $48 / 59$ \\
\hline Langau-nat & European larch & $3 / 12$ & $37 / 28$ & $60 / 55$ & $-/ 5$ & $-/-$ & $40 / 40$ & $100 / 95$ \\
\hline Montgenèvre-nat & European larch & $66 / 60$ & $7 / 19$ & $27 / 21$ & $-1-$ & $-/-$ & $73 / 79$ & $100 / 100$ \\
\hline Ina-F & Japanese larch & $25 / 37$ & $30 / 24$ & $35 / 29$ & $5 / 5$ & $5 / 5$ & $55 / 61$ & $90 / 90$ \\
\hline Hybrid-F & Hybrid larch & $-/ 3$ & 43 / 42 & $57 / 52$ & $-/ 3$ & $-/-$ & $43 / 45$ & $100 / 97$ \\
\hline Hybrid-GB & Hybrid larch & $-/ 1$ & $6 / 11$ & $88 / 74$ & $6 / 13$ & $-1-$ & $6 / 12$ & $94 / 86$ \\
\hline
\end{tabular}

Blizyn-D, Montgenèvre-nat or Ina-F experienced average mass losses lower than $12 \%$, others (Langau-B, Ruda-D or Hybrid-GB) presented average mass losses nearly twice as high. Wood lots such as Montgenèvre-nat would thus be classified in durability class 2 (durable) while Langau-B would fall into class 4 (slightly durable). Large variability also existed among trees within wood lots and among wood samples within wood lots (Tab. IV).

The native alpine wood lot from Montgenèvre showed exceptional decay resistance against fungi; more than $60 \%$ of its trees and samples were classified as 'very durable'. Excluding Langau-B, Zabreh-F, Zabreh-B and Montgenèvre-F, 70\% or more of trees (more than $61 \%$ of samples) from all origins fell at least into class 3, considered therefore as 'moderately' to 'highly durable'.

The wood lots with the highest frequency of durable (classes 1 and 2) trees and samples included provenances of native alpine old larches as well as some fast growing provenances of Japanese (Ina-F), hybrid (Hybrid-F) and European (Blizyn-D) larches.

The large variability among wood lots masked different sources of variation such as site, species, genetic origin and age of trees. These effects were subsequently analysed.

\subsection{Site effect}

Different wood lots were collected from different sites, therefore it was not possible to directly compare provenances and derive population genetic effects unless a statistical comparison confirmed the absence of significant site effects on decay resistance.

The Ruda and Zabreh provenances which had each been established in lowland plantations at the same age, allowed testing for the possible existence of a site effect. Although sites were contrasted for climate as well as for growth (Tabs. I and II), no difference in decay resistance was observed between the two sites (Tab. V). Interactions between site and provenance effects were not significant.

In contrast, comparison of Ruda provenance which was available in 3 provenance trials produced a highly significant
Table V. Site influence on the average mass loss (\%) for two provenances (Ruda \& Zabreh).

\begin{tabular}{lcccc}
\hline Variation source & Degrees of freedom & MS & $F$-value & $p$ \\
\hline Site $(\mathrm{B}, \mathrm{F})$ & 1 & 321.6 & $2.41 \mathrm{~ns}$ & 0.3644 \\
Provenance (Ruda, Zabreh) & 1 & 26.6 & $0.14 \mathrm{~ns}$ & 0.7091 \\
Site $\times$ Provenance & 1 & 133.5 & $0.70 \mathrm{~ns}$ & 0.4035 \\
Residual error & 310 & 190.8 & & \\
\hline
\end{tabular}

site effect $(F=22.53, p<0.0001, d f=2,272)$; wood decay resistance for this provenance was significantly lower in Elm site than in the other two sites.

While trees from Langau and Montgenèvre had the same genetic origins in native mountainous and artificial lowland forests, it was not possible to directly test the site effect on wood decay resistance due to different tree ages. Nevertheless, it was noted that wood samples from native stands were on average more resistant than those from lowland stands, with the percentage of mass loss approximately double in the lowland stands compared with the native stands.

Based on these results, further comparisons were confined to wood lots from the Belgian and French sites in order to avoid unknown site effects and age effects. This allowed a better comparison among genetic material (species and provenances).

\subsection{Genetic effects}

Genetic effects could be studied at three different levels including species, races and provenances within European larch.

Highly significant differences among species were observed according to Tukey's test; Japanese larch was significantly more decay resistant (average mass loss: $9.0 \pm 1.0 \%$ ) than hybrid (average mass loss: $16.9 \pm 0.5 \%$ ) and European larches (average mass loss : $18.6 \pm 0.7 \%$ ).

European larch provenances from the Belgian and French sites could be gathered into two well known larch races: those from the Sudetan Mountains including Ruda and Zabreh provenances, and those from the Alps with Langau and Montgenèvre provenances. Decay resistance of wood from the 
Table VI. Effect of race, provenance and tree factors on natural durability.

\begin{tabular}{lcccc}
\hline Variation source & Degrees of freedom & MS & $F$-value & $p$ \\
\hline Race & 1 & 3687.2 & $3.49 \mathrm{~ns}$ & 0.1350 \\
Provenance (race) & 4 & 1055.5 & $3.23^{*}$ & 0.0150 \\
Tree (provenance race) & 111 & 326.3 & $1.98^{* *}$ & $<0.0001$ \\
Residual error & 347 & 164.9 & & \\
\hline
\end{tabular}

Table VII. Average mass loss in percent $(\% \pm \mathrm{SE})$ for European larches in Nassogne (B) and Coat-An-Noz (F) sites.

\begin{tabular}{lcc}
\hline Provenance & Race & Average mass loss $(\%)$ \\
\hline Montgenèvre & Alps & $17.3( \pm 1.66)$ \\
Langau & & $27.7( \pm 1.83)$ \\
\hline Average & & $22.7( \pm 1.31)$ \\
\hline Ruda & Sudetan Mts & $16.4( \pm 1.09)$ \\
Zabreh & & $17.0( \pm 1.12)$ \\
\hline Average & & $16.7( \pm 0.78)$ \\
\hline
\end{tabular}

alpine provenances did not differ significantly from Sudetan Mountains provenances as shown in Table VI.

Significant differences for wood decay were also found between provenances within races of European larch. Large differences were observed between the two provenances from the Alps, with wood decay resistance of Langau appearing lower than that of Montgenèvre (Tab. VII). Decay resistance of Montgenèvre was within the range of the provenances from the Sudetan Mountains. Therefore, observed differences between provenances (Tab. VII) were only due to the low natural durability of Langau-B.

Analysis of variance (Tab. VI) also highlighted the existence of an important intra-provenance variability $(F=1.98$, $p<0.0001, d f=111,347)$. For a provenance presenting on average a lower resistance to wood decay, it was possible to identify some trees with good resistance to fungal attack. Ruda-F provenance could be considered on average as 'moderately durable' (Fig. 3a) but some trees were classified as 'very durable' while others were not resistant to wood decay. The level of variability between trees differed according to provenances: for some provenances it is possible to find trees in each durability class while for others (such as Zabreh-F), the durability level varied across only one durability class around the median.

An important variability was also observed between wood samples within trees (Fig. 3b). Whatever the provenance, it was possible to classify wood samples into each durability class: some trees of Langau-B were considered as 'slightly durable', but within those trees, some 'very durable' wood samples were identified.

\section{DISCUSSION}

On average, larch heartwood was classified as 'moderately durable' (class 3) according to the European standard EN 3501 (1994). This result supports European standard EN 350-2 (1994) where larch wood shares classes 3 and 4 with Scots pine and Douglas fir and supports a number of previous reports for different larch species (Gambetta et al., 2004; Nilsson, 1997; Viitanen et al., 1997). Based on a restricted wood sample (3 logs per species), Viitanen et al. (1997) considered larch species (L. decidua, L. sibirica, L. gmelinii, L. gmelinii var. japonica, $L$. Gmelinii var. olgensis, $L$. sibirica $\times$ decidua), as 'moderately' to 'slightly durable' (class 3 or 4). Conversely, Gambetta et al. (2004) graded European larch heartwood from 3 Italian alpine sites ( 3 trees per site) into durability classes 3 (moderately durable) and 2 (durable) depending on the site. This ranking was also confirmed by Nilsson (1997).

Considering only the average performance of larch for wood decay resistance may be misleading as the huge variability existing among wood samples is ignored. This study identified several additional sources of variation.

While the origins of the wood samples made it difficult to separate genetic from environmental sources of variation, genetics seems to play a significant role in decay resistance at three different levels: species, provenance and individual tree levels. This possibility was supported by restricting the analysis to the two lowland even aged plantations of Coat-An-Noz (F) and Nassogne (B). Among the three species available in these sites, Japanese larch appeared to be the most durable (decay resistant). Although the observed sample concerned only one population, 20 trees were evaluated which represented a large sample for such a study. On a smaller sample (5 Japanese and 3 European larches), Pechmann and Schaile (1955) also found Japanese larch to be the most decay resistant. In our study, European and hybrid larches were generally similar to each other.

Highly significant variability existed amongst the European larch originating from lowland plantations: central Poland race was classified as the most durable, followed successively by the Sudetan and alpine races. This conclusion should be however confirmed using a larger set of provenances.

Species and provenance effects did not explain all the observed variability: a large proportion of variability occurred at the tree within provenance level. Previous works confirmed this observation for European larch (Gambetta et al., 2004) and for other species of the same genus such as tamarack (Srinivasan et al., 1999) and Siberian larch (Venäläinen et al., 2001). In the latter species, the authors highlighted the genetic control for wood decay resistance at the clonal level. In other species such as Pinus sylvestris, significant genetic variation was observed at the family level (Harju and Venäläinen, 2002; Harju et al., 2001).

Apart from the influence of genetic factors, the effects of several environmental factors were highlighted.

No significant site effects could be observed when considering decay resistance of the same genetic populations in two ecologically contrasting sites (Nassogne and Coat-An-Noz). This result agrees with that published by the US Forest Service (1967) which noted that environmental influences such as rainfall or soil had only a small effect on decay resistance of heartwood of native species. However, some elements of the behaviour of Ruda provenance at the German site (Elm) may contradict this assumption for other sites. 
(a)

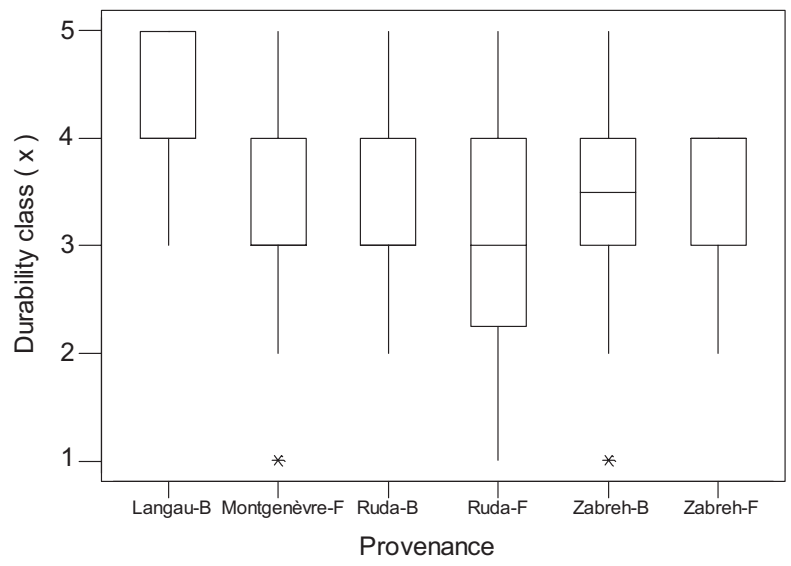

(b)

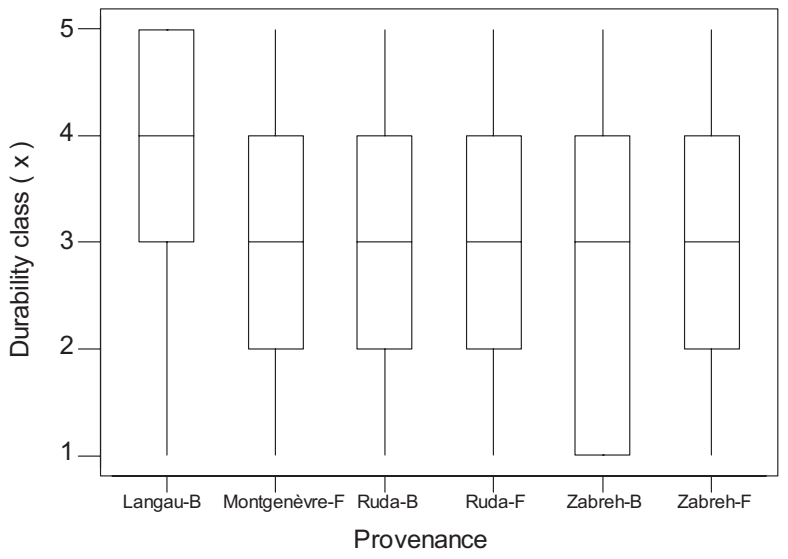

Figure 3. Intra-provenance variability of wood decay resistance at tree (a) and wood sample (b) levels.

Samples from old trees ( $>180 \mathrm{y}$ ) collected in natural stands in the Alps appeared as the most decay resistant. Wood from the same Alpine origins grown in lowland plantations did not exhibit this resistance. Local growth conditions, age and maturity of wood may be more relevant than genetic effects. Venäläinen et al., (2001) compared decay resistance of increment cores of Siberian larch from 11 plus trees (aged between 56 and 88 y) with samples from their young grafted copies taken in a 25 years old seed orchard. Weight losses tended to be higher in wood from the juvenile grafted trees compared to the more mature individuals, although the results did not differ significantly.

Differences in decay resistance observed between different wood samples from the same tree tend also to suggest that genetics, site and tree age are not the only factors contributing to the natural durability of a wood sample. Intra-tree variability also appears to be a significant factor. The radial position of the sample significantly influences the decay resistance of the wood. European larch samples collected in the inner part of the heartwood were significantly less decay resistant than wood samples sawn closer to sapwood. This tendency has already been reported for European larch by Gambetta et al. (2004) and for Hybrid larch by Windeisen et al. (2002). Similar results were also obtained by Venäläinen et al. (2003) for old Scots pines. The influence of radial position on decay resistance is likely related to the increase in heartwood extractives from pith to heartwood sapwood boundary as previously observed in old Langau and Montgenèvre trees (Gierlinger and Wimmer, 2004). A close link between extractives content and natural durability was described for larch by Gierlinger et al. (2004b) and Windeisen et al. (2002).

The strong genetic control of heartwood content in trees (Pâques, 2001) combined with the high variability observed in this study at different genetic levels for wood decay resistance indicate that breeding and selection for quantitative and qualitative improvement of heartwood durability in larch is possible. In order to carry out thorough studies, nondestructive, low cost and low time consuming techniques for routine screening of wood decay resistance will be needed. Clearly the European standard EN 350-1 (1994) methodology cannot be used for that purpose within selection schemes. Biological tests on increment cores (Harju et al., 2001; Venäläinen et al., 2001) would already represent an improvement but other indirect assessments through wood colour determination (Gierlinger et al., 2004a), extractives content analysis (Gierlinger, 2003; Windeisen et al., 2002) or NIR spectrometry such as proposed for larch by Gierlinger et al. (2002; 2003) should be preferred.

\section{CONCLUSIONS}

A wide variability for wood decay resistance to fungi was observed among and within wood lots of various genetic origins of larch collected across Europe. Natural durability ranged from class 1 (very durable) to class 5 (not durable) according to the EN 350-1 standard (1994). Our results confirmed its complex origin which can be attributable to several factors including genetics (species, races, provenances) and ontogenesis (position along the radius, age) but no clear site influence was detected.

More durable wood was not exclusively found from old native alpine stands of European larch since it also occurred in trees from some lowland plantations. Some populations used in breeding programmes and recommended as varieties for reforestation appeared promising. This was the case of some populations of European larch from Eastern Europe, but also of Japanese and hybrid larches.

Genetic improvement of larch wood durability appeared therefore likely by the selection of the best populations for decay resistance as well as from the selection of individuals. However, the heritability of this character is still unknown.

Development of a quick, cheap and reliable method of investigation of wood decay resistance is a prerequisite for routine screening of trees during breeding process but also for a more precise classification of wood pieces in industrial processes. 
Acknowledgements: The authors are grateful to two anonymous reviewers for their valuable comments and suggestions to improve the manuscript. This study was funded by the European Union, Fair project CT98 - 3354 "Towards a European Larch Wood Chain”.

\section{REFERENCES}

Collardet J. and Besset J., 1988. Bois commerciaux, Tome 1, les résineux (conifères), CTBA, 278 p.

Fields S., 2001. Caution-children at play: how dangerous is CCA? Environ. Health Perspective, 109: 262-269.

Gambetta A., Susco D., and Zanuttini R., 2004. Determination of the natural durability of larch wood (Larix decidua Mill.) from the Western Italian Alps. Holzforschung 58: 678-681.

Gierlinger N., 2003. Chemistry, colour and brown-rot decay resistance of larch heartwood and FT-NIR based prediction models, Dissertation, Universität für Bodenkultur, Wien, $129 \mathrm{p}$.

Gierlinger N. and Wimmer R., 2004. Radial distribution of heartwood extractives and lignin in mature European larch. Wood Fiber Sci. 36: 387-394.

Gierlinger N., Jacques D., Marchal M., Wimmer R., Schwanninger M., and Pâques L.E., 2002. Heartwood extractives and natural durability of larch - Relationships and their prediction by FT-NIR spectroscopy. In: Proceedings of an International Symposium, Gap (Hautes-Alpes) - Auvergne \& Limousin, September 16-21, pp. 414-421.

Gierlinger N., Jacques D., Schwanninger M., Wimmer R., Hinterstoisser B., and Pâques L.E., 2003. Rapid prediction of natural durability of larch heartwood using Fourier transform near-infrared spectroscopy. Can. J. For. Res. 33: 1727-1736.

Gierlinger N., Jacques D., Grabner M., Wimmer R., Schwanninger M., Rozenberg P., and Pâques L.E., 2004a. Colour of larch heartwood and relationships to brown-rot decay-resistance. Trees 18: 102-108.

Gierlinger N., Jacques D., Schwanninger M., Wimmer R., and Pâques L.E., 2004b. Heartwood extractives and lignin content of different larch species (Larix sp.) and relationships to brown-rot decayresistance. Trees 18: 230-236.

Harju A.M. and Venäläinen M., 2002. Genetic parameters regarding the resistance of Pinus sylvestris heartwood to decay caused by $C$. Puteana. Scand. J. For. Res. 17: 199-205.

Harju A.M., Venäläinen M., Beuker E., Velling P., and Viitanen H., 2001. Genetic variation in the decay resistance of Scots pine wood against brown rot fungus. Can. J. For. Res. 31: 1244-1249.

Jacques D., 1991. Synthèse des résultats des tests de provenances de mélèze d'Europe en Belgique. Trav. Sta. Rech. Forest., Gembloux, Sér. E, 8, 39 p.

Jacques D., Curnel Y., Jourez B., and Pâques L.E., 2002. Among and within provenance variability for decay resistance of larch wood to fungi. Improvement of Larch (Larix sp.) for better growth, stem form and wood quality. In: Proceedings of an International Symposium, Gap (Hautes-Alpes) - Auvergne \& Limousin, September 16-21, pp. 405-413.

NBN- EN 350-1, 1994. Durabilité du bois et des matériaux dérivés du bois - Durabilité naturelle du bois massif - Partie 1: Guide des principes d'essai et de classification, de la durabilité naturelle du bois.

NBN- EN 350-2, 1994. Durabilité du bois et des matériaux dérivés du bois - Durabilité naturelle du bois massif - Partie 2: Guide de la durabilité naturelle du bois et de l'imprégnabilité d'essences de bois choisies pour leur importance en Europe.

Nilsson T., 1997. Natural durability of larch heartwood against decay. Internat. Res. Group on Wood Pres., Stockholm, IRG Doc. No. IRG/WP 97-10201, $22 \mathrm{p}$.

Pâques L., 1989. A critical review of larch hybridization and its incidence on breeding strategies. Ann. Sci. For. 46: 141-153.
Pâques L.E., 1996a. Variabilité naturelle du mélèze. I. Mélèze d'Europe: bilan de 34 ans de test comparatif de provenances. Ann. Sci. For. 53: $51-67$.

Pâques L.E., 1996b. Variabilité naturelle du mélèze. II. Mélèze du Japon: bilan de 36 ans de test comparatif de provenances. Ann. Sci. For. 53: 69-78.

Pâques L.E., 2001. Genetic control of heartwood content in larch. Silvae Genet. 50: 69-75.

Pâques L.E., 2002. Heterosis in interspecific hybrids between European and Japanese larch. Improvement of Larch (Larix sp.) for better growth, stem form and wood quality. In: Proceedings of an International Symposium, Gap (Hautes-Alpes) - Auvergne \& Limousin, September 16-21, pp. 155-163.

Pechmann von H. and Schaile O., 1955. Untersuchtungen über die Holzeigenschaften japanischer Lärchen. Forstwiss. Centr. B1. 74: 87113.

Philippe G., Curnel Y., Jacques D., Lee S., and Matz S., 2002. Performances of hybrid larch (Larix $\times$ eurolepis Henry) varieties across Europe: early results for survival, stem form and growth rate. In: Improvement of Larch (Larix sp.) for better growth, stem form and wood quality, proceedings of an International Symposium, Gap (Hautes-Alpes) - Auvergne \& Limousin, September 16-21, pp. 127139.

Rapp A., Viitanen H., and Nilsson T., 2002. The influence of natural durability of four different Larix species to their possible end-use in construction industry. In: Wood in construction industry: prospectives of reconstruction, Inter. Conf. Proc., Zagreb, Croatia, 19th April, pp. 11-16.

R Development Core Team, 2005. R: A language and environment for statistical computing, R Foundation for Statistical Computing, Vienna, Austria. URL http://www.R-project.org.

Sailer M. and van Etten B., 2004. Potential wood protection strategies using physiological requirements of wood degrading fungi. HERON 49: 327-337.

SAS Institute Inc, 2003. SAS for windows, Cary, NC, USA.

Schneck V., Schneck D., Grotehusmann H., and Pâques L.E., 2002. Techniques of hybrids larch over a broad range of site conditions. In: Improvement of Larch (Larix sp.) for better growth, stem form and wood quality, proceedings of an International Symposium, Gap (Hautes-Alpes) - Auvergne \& Limousin, September 16-21, pp. 119126.

Schöber R., 1977. Vom II. Internationalen Lärchenprovenienzversuch. Ein Beitrag zur Lärchenherkunftsfrage. Schriftenreihe der Forestlichen Fakultät Göttingen, 358 p.

Srinivasan U., Ung. T., Taylor A., and Cooper P.A., 1999. Natural durability and waterborne preservative treatability of tamarack. For. Prod. J. 49: 82-87.

US Forest Service, 1967. Comparative Decay Resistance of Heartwood of Native Species, Research note FPL 0153, 2 p.

Van Acker J., Stevens M., Carey J., Sierra-Alvarez R., Militz H., Le Bayon I., Kleist G., and Peek R.D., 2003. Biological durability of wood in relation to end-use. Holz Roh Werkst. 61: 35-45.

Venäläinen M., Harju A.M., Nikkanen T., Paajanen L., Velling P., and Viitanen H., 2001. Genetic variation in the decay resistance of Siberian larch (Larix sibirica Ledeb.) wood. Holzforschung 55: 1-6.

Venäläinen M., Harju A.M., Kainulainen P., Viitanen H., and Nikulainen, 2003. Variation in the decay resistance and its relationship with other wood characteristics in old Scots pines. Ann. For. Sci. 60: 409-417.

Viitanen H., Paajan L., Saranpaa P., and Viitaniemi P., 1997. Durability of larch (Larix spp.) wood against brown-rot fungi. Group on Wood Pres., Whistler, BC, Canada, IRG Doc. N $^{\circ}$ IRG/WP 97-10228, 8 p.

Windeisen E., Wegener G., Lesnino G., and Schumacher P., 2002. Investigation of the correlation between extractives content and natural durability in 20 cultivated larch trees. Holz Roh Werkst. 60: 373-374. 